\title{
The Effects of Development Program in ITERA Dormitory for Student Learning Achievements in First Year Stage Course
}

\author{
Triyana Muliawati ${ }^{1}$, Dewi Suhika ${ }^{1}$ \\ ${ }^{1}$ Mathematics Department, Institut Teknologi Sumatera, Lampung Selatan, Lampung
}

\begin{abstract}
The development of student character starts from education process in campus life and residence. The environment is less comfortable and effective in the learning process will affect student achievement. To overcome this, the Institute of Technology of Sumatra (ITERA) provides a new student dormitory which one of the place that can provide an effective learning environment because the coaching programs provided such as peer tutors aim to develop learning achievement in TPB Program. The relationship of coaching program in the dormitory to student achievement on First Year Stage Course (TPB) can be analyze use simple regression method. The data that used in this method are questionnaire, mid test score and final test, especially in Basic Mathematics. The results of the analysis stated that the coaching program at the Dormitory resulted in higher learning achievement than those outside the dormitory.
\end{abstract}

\section{Introduction}

Character development of a nation becomes very important to build the character of the nation itself. In Indonesia, the development of national character is carried out by means of intervention and habitation, which is formed through formal education (academic, co-curricular, and extra-curricular), family, and society. The Sumatra Institute of Technology (ITERA) is a campus in South Lampung, Sumatra. ITERA aims to promote, develop and disseminate science, technology, art, humanity, to improve the welfare of the people of Sumatra in particular, and the Indonesian people are in line with the dynamics of the Indonesian people and the world community, while upholding social, humanitarian and environmental values through the Tridharma college vehicle. For the purpose of creating this goal, ITERA has a program called the Joint Preparation Stage (TPB). TPB provides a foundation for science, art and technology for new students. In addition, TPB serves as a vehicle for early development of scientific attitudes and adaptation of the procedures for studying in universities. A strong foundation of science is given through the Basic Mathematics course. Initial coaching to support TPB is provided through the ITERA Dormitory by requiring students at TPB to stay in the Dormitory for 1 year. ITERA dormitories have development programs such as peer tutors who are able to improve the quality of student learning. Peer tutors are a group of students who have completed learning materials, giving assistance to students who have difficulty understanding the material they learned [1]. Peer-tutoring is defined as involving students learning from and with each other in ways which are mutually beneficial and involve sharing knowledge, ideas, and experiences among participants [2]. Peer-tutoring is systematic, peer-mediated teaching strategies [3]. Peer tutoring has been demonstrated to be successful in promoting the academic and social skills of general education students as well as special education students, including students who were identified as at-risk [4]. 
A student is said to have achieved its development optimally if students can get education and learning achievements that are in accordance with their talents, abilities, and interests. One of the results that can be used as a reference is learning achievement, in this case learning achievement when at TPB. Learning achievement is a value that reflects the levels of students to what extent they have achieved the goals set in each field of study [5]. The intellectual ability of students determines the success of students in obtaining achievements. To find out whether or not someone is successful in learning, it is necessary to do an evaluation, the goal is to find out the achievements of students after the teaching and learning process takes place. Based on previous research, there are factors that can affect student achievement including coaching programs. This factor is important to be re-examined because in previous studies, it was proven that peer-tutoring has a positive impact on academic outcomes such as agricultural science [6], reading [7], mathematics [8], and spelling and other subjects [9] so learning achievement students increase significantly.

Based on various problems identified in TPB ITERA, researchers were interested in conducting research to compare the learning outcomes of students living in dormitories and outside dormitories in the 2017/2018 FY TPB and analyzing how effective the relationship between the boarding process in the dormitory and the students who lived in the dormitory FY 2017/2018.

\section{Methodology}

This research was carried out at Institut Teknologi Sumatera (ITERA), South Lampung, Sumatera. The population in this study were all TPB students for the 2017/2018 school year consisting of 20 TPB classes totaling 1.514 students. In this study the sample was 320 students. The form of this research is a comparative research which is intended to determine the effect of the ITERA dormitory development program on TPB student achievement. The variables in this study include the dependent variable that is Learning Achievement ( $\mathrm{Y}$ ) and the independent variable is the Development Program (X). The first step is to measure the learning achievement of students living in dormitories and outside the dormitory of ITERA. Researchers use the documentation of the Middle Semester Examination (UTS) and Odd End Semester (UAS) Examinations on basic mathematics.

Questionnaire method (questionnaire) was used to obtain data regarding the training program in the ITERA dormitory. Questionnaires are prepared based on research variables and research indicators with an instrument measurement scale using a Likert scale. Instrument testing includes validity and reliability. Validity is a measurement that shows the levels of validity and error of an instrument. Reliability shows the understanding that the instrument can be trusted enough to be used as a data collection tool for instruments that are good enough [7]. Prerequisite testing uses linearity test, normality test, and multicollinearity test. While testing the hypothesis using regression analysis and $\mathrm{F}$ test. All testing is done with the help of SPSS 23 for Windows.

\section{Experimental Result and Discussion}

\subsection{Comparison of Learning Achievments}

Data of student learning achievement is taken from the documentation of the UTS and UAS in the basic mathematics courses. In Figure 1, it can be seen that the average value of basic mathematics learning achievement of students living in the dormitory is 71.57 and outside the dormitory is 60.76 . This means that the learning achievement of students living in dormitories is $15.10 \%$ higher than the learning achievement of students living outside the dormitory at TPB. 


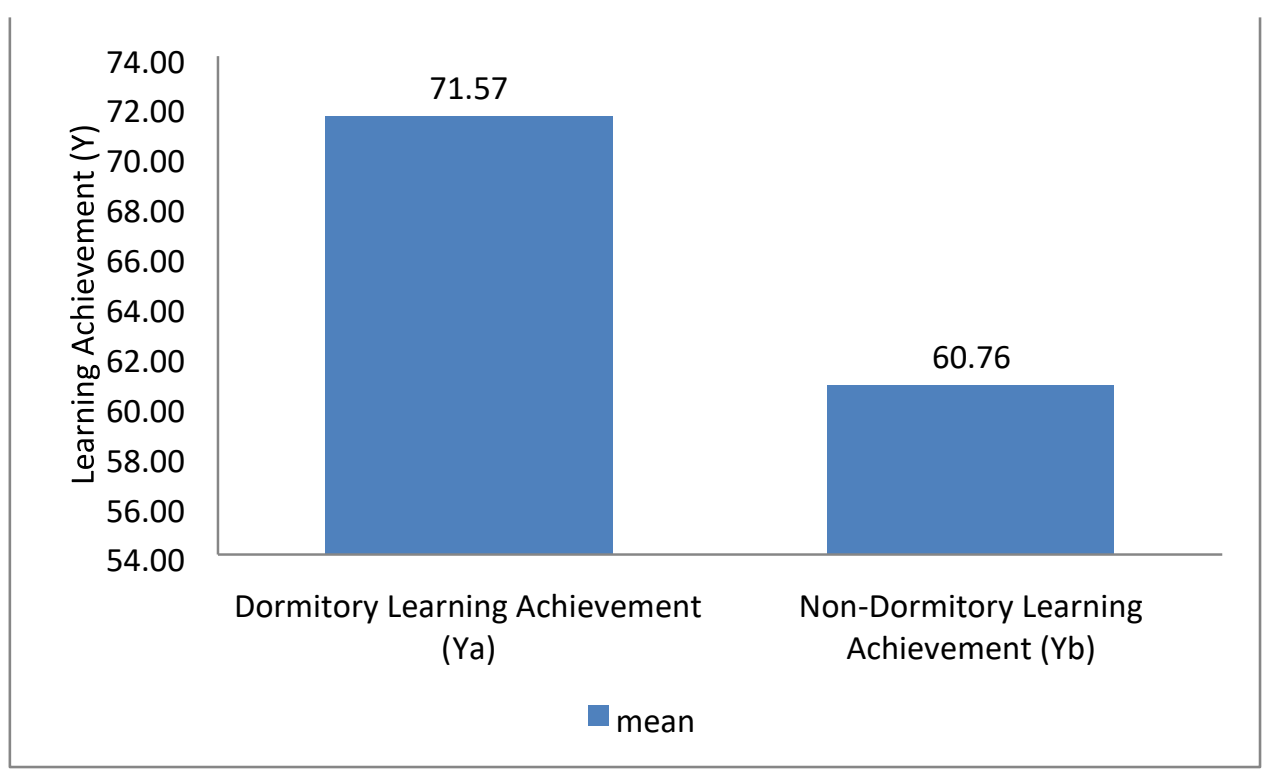

Figure 1. Comparison of learning achievement in basic mathematics

\subsection{Relationship of the Development Program to Learning Achievement}

\subsubsection{Instrument Test}

Instrument testing is done by testing the validity and reliability. In testing the validity of the questionnaire can be done by analyzing the factors and analysis of the items. In this study using the analysis of items to test the validity of each item, the scores on each item were correlated with the total score. The decision-making item is based on probability, if the probability is greater than 0.1097 then the items in the research can be used. Based on these probabilities, items that can be used in this study amount to 19 questions out of 20 questions. Reliability testing in this study uses Cronbach's Alpa more than 0.6 with the results in table 1, namely the value of Cronbach's Alpha coaching program shows the coefficient value of 0.925 is greater than 0.6 , the instrument of the program is reliable. Tabel 1 . Reliability Statistics

\begin{tabular}{|l|r|}
\hline $\begin{array}{l}\text { Cronbach's } \\
\text { Alpha }\end{array}$ & N of Items \\
\hline .925 & 19 \\
\hline
\end{tabular}

\subsubsection{Linearity Test}

Linearity test can be seen from the value of $F$ (Deviation from linearity) as in Table 2. The value of $F$ which produces $\mathrm{X}$ against $\mathrm{Y}$ is 1.363 and $\mathrm{F}_{\text {table }}$ is 1.32 with a significant value of more than $5 \%$ that is equal to 0.064 . Because the significant level produced exceeds $5 \%$ and $\mathrm{F}$ value is more than Ftable, the relationship between coaching program $(\mathrm{X})$ and learning achievement $(\mathrm{Y})$ is linear. Tabel 2. Anova

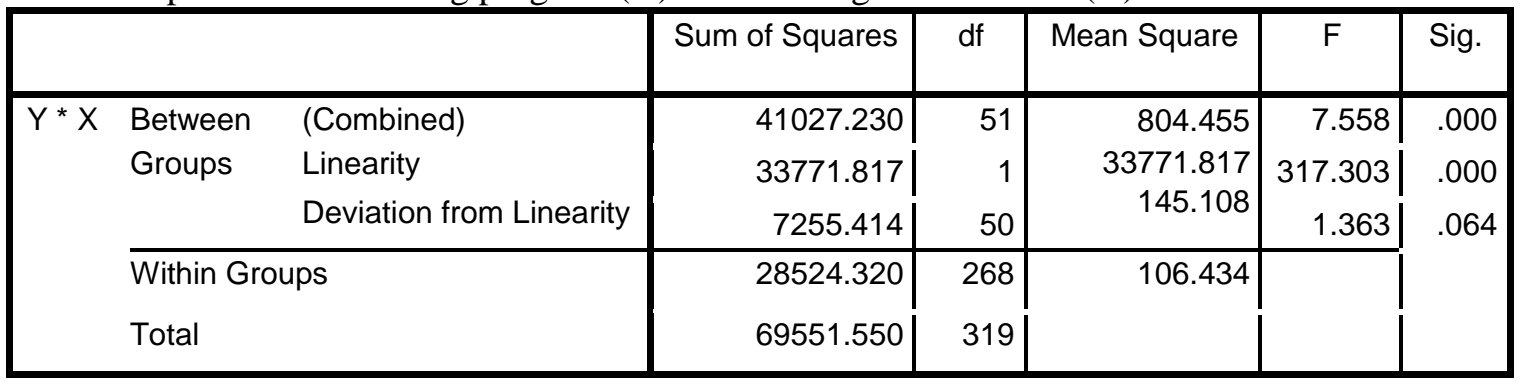




\subsubsection{Normality Test}

Normality test using Kolmogorov Smirnov Test can be seen in Table 3 with the results of the Sig. that is equal to 0.53 for $\mathrm{Y}$ and 0.2 for $\mathrm{X}$. The significance level generated by $\mathrm{Y}$ is 0.53 and $\mathrm{X}$ is 0.2 more than 5\%, thus the assumption of data normality is fulfilled. In Figure 2 and Figure 3, it can be seen that the curves at $\mathrm{Y}$ and $\mathrm{X}$ are shaped like bells which means that the data on $\mathrm{Y}$ and $\mathrm{X}$ are normally distributed.

Tabel 3. Tests of Normality

\begin{tabular}{|l|r|r|r|r|r|r|}
\hline \multirow{2}{*}{} & \multicolumn{3}{|c|}{ Kolmogorov-Smirnov $^{\mathrm{a}}$} & \multicolumn{3}{c|}{ Shapiro-Wilk } \\
& Statistic & \multicolumn{1}{c|}{$\mathrm{df}$} & \multicolumn{1}{c|}{ Sig. } & Statistic & \multicolumn{1}{c|}{ df } & \multicolumn{1}{c|}{ Sig. } \\
\hline $\mathrm{Y}$ & .050 & 320 & .053 & .991 & 320 & .057 \\
$\mathrm{X}$ & .040 & 320 & $.200^{*}$ & .989 & 320 & .016 \\
\hline
\end{tabular}

${ }^{\star}$. This is a lower bound of the true significance. a. Lilliefors Significance Correction

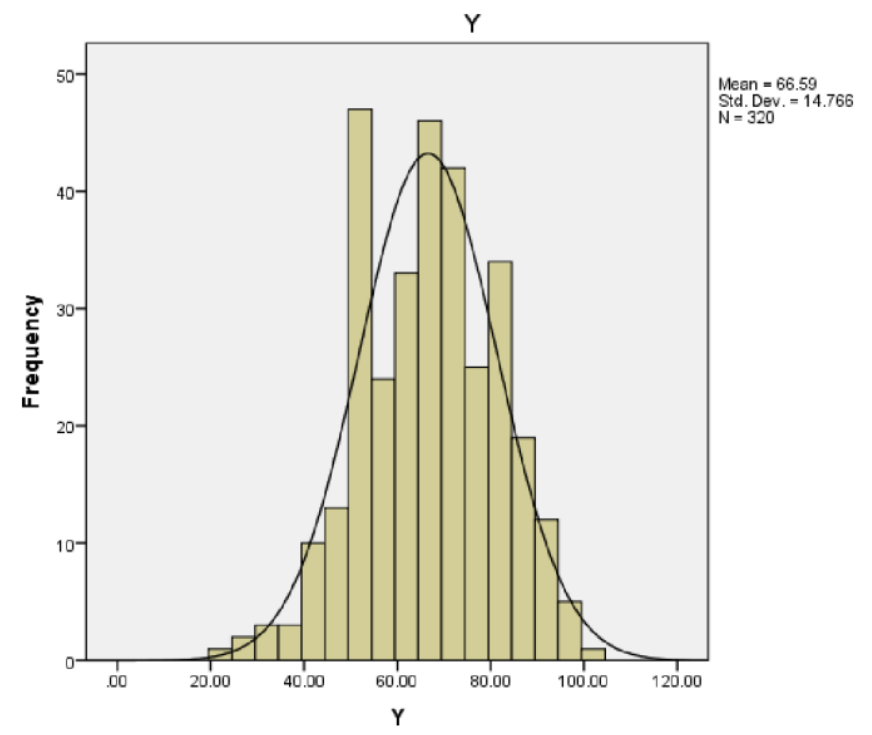

Figure 2. Learning achievement $(\mathrm{Y})$ curve 


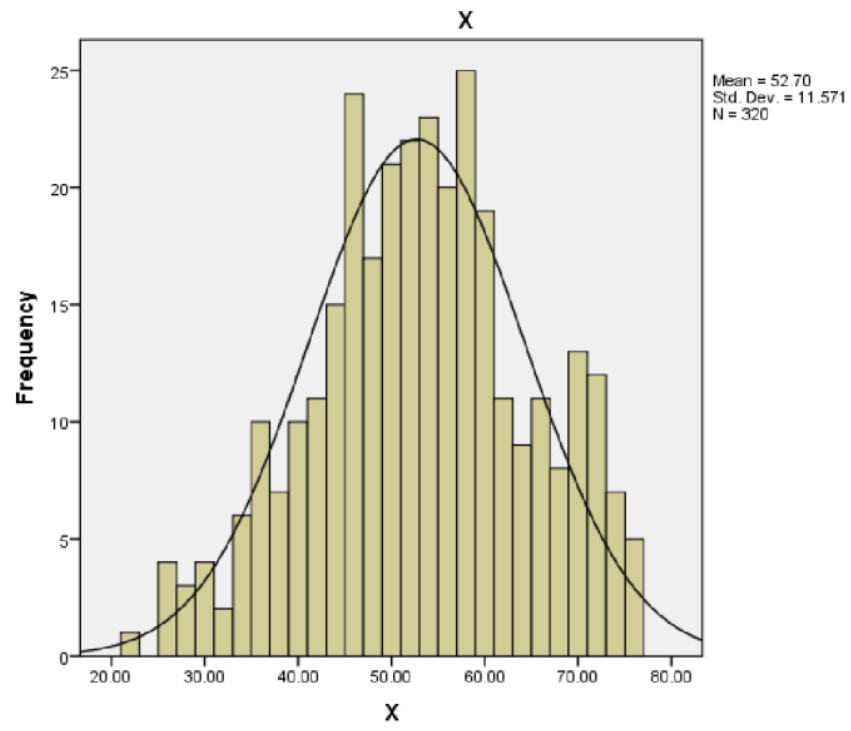

Figure 3. Development program $(\mathrm{X})$ curve

\subsubsection{Multicollinearity Test}

Multicollinearity test is shown by table 4 coefficients by observing Collinearity Statistics in the tolerance column and VIF column. Obtained tolerance values of both variables is more than 0.1 , which is 1.0 and the VIF value of both variables is less than 10 , which is 1.0. Thus there is no multicollinearity between independent variables in the regression model.

Regression models obtained based on the results of the research in table 4 in the Unstandardized oefficients column, can be written in the form of regression equations are as follows:

$$
Y=19.726+2.769 X
$$

with

$\mathrm{X}=$ development program

$\mathrm{Y}=$ student learning achievement in basic mathematics

From the above equation, the independent variable $\mathrm{X}$ has a regression coefficient with a positive direction of 2.769. This means that every additional point in the dormitory program, the learning achievement of TPB students in basic mathematics courses will increase by 2.769 .

The hypothesis in this study is the influence of coaching programs at ITERA dormitory on student learning achievement at TPB. F test results based on Table 5 Anovaa or F statistical test, the model shows the Fcount value of 300.154 is greater than Ftable of 3.84 with a significance value of 0.000 . smaller than $5 \%$. Based on the decision criteria $\mathrm{H}_{0}$ is accepted, so that the conclusion obtained is the influence of the training program significantly on the achievement of learning achievement.

The magnitude of the effect of coaching programs simultaneously on learning achievement can be seen from the coefficient of determination (R-Square) in Table 6. The results of the correlation coefficient is 0.486 , which means $48.6 \%$ learning achievement is influenced by the coaching program and $51.4 \%$ is influenced by other variables.

Tabel 4. Coefifients 


\begin{tabular}{|c|c|c|c|c|c|c|c|}
\hline \multirow[b]{2}{*}{ Model } & \multicolumn{2}{|c|}{$\begin{array}{l}\text { Unstandardized } \\
\text { Coefficients }\end{array}$} & \multirow{2}{*}{$\begin{array}{c}\text { Standardized } \\
\text { Coefficients } \\
\text { Beta }\end{array}$} & \multirow[b]{2}{*}{$\mathrm{t}$} & \multirow[b]{2}{*}{ Sig. } & \multicolumn{2}{|c|}{$\begin{array}{l}\text { Collinearity } \\
\text { Statistics }\end{array}$} \\
\hline & B & Std. Error & & & & Tolerance & VIF \\
\hline (Constant) & 19.726 & 2.769 & & 7.124 & .000 & & \\
\hline$X$ & .889 & .051 & .697 & 17.325 & .000 & 1.000 & 1.000 \\
\hline
\end{tabular}

a. Dependent Variable: $Y$

Tabel 5. Anova $^{a}$

\begin{tabular}{|c|c|c|c|c|c|c|}
\hline \multicolumn{2}{|c|}{ Model } & \multirow{2}{*}{$\begin{array}{r}\text { Sum of Squares } \\
33771.817\end{array}$} & \multirow{2}{*}{$\begin{array}{ll}d f & \\
& 1\end{array}$} & \multirow{2}{*}{\begin{tabular}{|r|} 
Mean Square \\
33771.817
\end{tabular}} & \multirow{2}{*}{$\begin{array}{c}\mathrm{F} \\
300.154\end{array}$} & \multirow{2}{*}{$\begin{array}{l}\text { Sig. } \\
.000^{\mathrm{b}}\end{array}$} \\
\hline 1 & Regression & & & & & \\
\hline & Residual & 35779.733 & 318 & 112.515 & & \\
\hline & Total & 69551.550 & 319 & & & \\
\hline
\end{tabular}

Tabel 6. Model Summary

\section{Conclusion}

\begin{tabular}{|l|c|c|c|c|}
\hline \multicolumn{1}{|c|}{ Tabel 6. Model Summary } \\
Model & $\mathrm{R}$ & $\mathrm{R}$ Square & $\begin{array}{c}\text { Adjusted R } \\
\text { Square }\end{array}$ & $\begin{array}{c}\text { Std. Error of the } \\
\text { Estimate }\end{array}$ \\
\hline 1 & $.697^{\mathrm{a}}$ & .486 & .484 & 10.60730 \\
\hline
\end{tabular}
a. Predictors: (Constant), X1

Based on the results of the study it can be concluded that the differences in basic mathematics learning achievement of students living in dormitories and outside dormitories at TPB 2017/2018 are as much as $15.10 \%$. So that TPB students are advised to stay in the dormitory and participate in coaching programs in the dormitory so that learning achievement can be further improved. There is a simultaneous influence between variables of boarding coaching programs on learning achievement. This means that coaching program variables together have a very significant influence on student achievement. In other words, the better the dormitory development program, the better student learning achievement will be. Deterimation coefficient (R-square) of 0.486 means that $48.6 \%$ variation in changes in learning achievement is explained by variations in changes in boarding coaching programs. While the rest of $51.4 \%$ is another factor that cannot be explained in this study. Dormitory building lecturers pay more attention to giving guidance programs to TPB students so that student learning achievements can be improved.

\section{References}

[1] San S, Ristiati Putu, Manik W 2013 Contextual Learning Model Assisted Peer Tutors on Biological Learning Outcomes Viewed from Learning Motivation Journal University of Ganesha Postgraduate Program p 3

[2] Boud D, Cohen R and Sampson J 2001 Peer-Learning in Higher Education: Learning from and with each other (Kogan Press: London, UK)

[3] Rohrbeck C A, Ginsburg-Block M D, Fantuzzo J W, and Miller T R 2003 Peer-Assisted Learning Interventions with Elementary School Students: A Meta-Analytic Review Journal of Educational Psychology 95 77-89 
[4] Nazzal A 2002 Peer-Tutoring and At-Risk Students: An Exploratory Study Action in Teacher Education 24(1) 68-80

[5] Irfan Setiawan 2013 Training and Development of Students at Boarding Institutions (CV. Smart Writing: Yogyakarta) p 8

[6] Adekoya and Olatoye 2011 Effect of Demonstration, Peer-Tutoring, and Lecture Teaching Strategies on Senior Secondary School Students Achievement in an Aspect of Agricultural Science The Pacific Journal of Science and Technology 12(1)

[7] Klingner J K and Vaughn S 1996 Reciprocal Teaching of Reading Comprehension Strategies for Students with Learning Disabilities who use English as a Second Language The Elementary School Journal 96(1) 89-101

[8] Fuchs L S, Fuchs D, and Karns K 2001 Enhancing Kindergartners Mathematical Development: Effects of Peer-Assisted Learning Strategies The Elementary School Journal 101

[9] Riggio R E, Fantuzzo J W, Connelly S, and Dimeff, L A 1991 Reciprocal Peer-Tutoring: A Classroom Strategy for Promoting Academic and Social Integration in Undergraduate Students Journal of Social Behavior and Personality 6(1) 90-109

\section{Acknowledgments}

This research was supported by Institut Teknologi Sumatera, ITERA Smart Research Grant. 